\title{
Hemşirelerde İnternet Bağımlılığı ve Zaman Yönetimi İlişkisinin Belirlenmesi
}

\section{Determination of the Relationship Between Internet Addiction and Time Management in Nurses}

\author{
Çetin Eroğlu ${ }^{1}$, Adalet Koca Kutlu ${ }^{2 *}$ \\ ${ }^{1}$ Manisa Celal Bayar Üniversitesi Sağlık Bilimleri Enstitüsü Yüksek Lisans Öğrencisi, Manisa, Türkiye \\ ${ }^{2}$ Manisa Celal Bayar Üniversitesi Sağlık Bilimleri Fakültesi Hemşirelik Bölümü, Manisa, Türkiye \\ e-mail: ctneroglu@windowslive.com, adalet.kutlu@cbu.edu.tr \\ ORCID: 0000-0002-2938-8972 \\ ORCID: 0000-0003-4417-5657 \\ *Sorumlu Yazar / Corresponding Author: Sorumlu Yazar: Doç. Dr. Adalet Koca Kutlu
}

Gönderim Tarihi / Received: 09.07.2019

Kabul Tarihi / Accepted: 03.04.2020

DOI: $10.34087 /$ cbusbed.589336

\section{$\ddot{\mathbf{O} z}$}

Giriş ve Amaç: Bu çalışma, hemşirelerde internet bağımlılığı ve zaman yönetimi ilişkisini incelemek amacıyla yapıld1.

Gereç ve Yöntemler: Tanımlayıcı ve açıklayıcı tipte olan bu çalışma, Sağlık Bilimleri Üniversitesi Tepecik Eğitim ve Araştırma Hastanesinde 15.04.2018-15.10.2018 tarihleri arasında yapıldı. Araştırmanın örneklemini hastanede servislerde çalışan ve çalışmaya katılmayı kabul eden 250 hemşire oluşturdu. Veri toplama araçları; Bilgi Formu, İnternet Bağımlılı̆̆ Ölçeği (İBÖ) ve Zaman Yönetimi Ölçeği (ZYA)'dir.

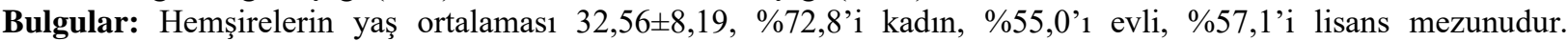
Hemşirelerin \%52,4'ünün zamanı kullanma durumunun orta düzeyde olduğu ve \%44,0'1nın 10 saatten az/haftada internette geçirdiği tespit edildi. İnternet Bağımlılı̆̆ Ölçeği ve alt boyutları; yoksunluk, kontrol güçlüğü, işlevsellikte bozulma, sosyal izolasyon sirasiyla 26,51 $\pm 9,38,18,96 \pm 7,53,12,51 \pm 5,84,11,40 \pm 5,15$ ve 69,66 24,43'tür. Zaman Yönetimi Anketi ve alt boyutlar1; zaman planlaması, zaman tutumları, zaman harcattırıcilar ve ZYA toplam puan ortalamaları sırasiyla 49,25 $10,97,23,46 \pm 4,25,13,20-3,28,86,00 \pm 14,79$ olarak bulundu. Hemşirelerin İBÖ ve alt boyutları ile ZYA ve alt boyutları arasındaki korelasyon orta, negatif ve anlamlı olarak belirlendi.

Sonuç: Hemşirelerin İBÖ ile ZYA puan ortalamaları arasında negatif yönde ve orta düzeyde bir ilişki bulundu. Örneklem sayılarının arttırılarak konuyla ilgili farklı gruplarda çalışmaların yapılması önerilebilir.

Anahtar Kelimeler: Hemşirelik, internet bağımlılı̆̆ı, zaman, zaman yönetimi

\footnotetext{
Abstract

Objective: This study was conducted to research the relationship between internet addiction and time management in nurses.

Materials and Methods: This descriptive study was performed at the Health Sciences University Tepecik Training and Research Hospital between 15.04.2018 and 15.10.2018. The universe of the study consisted of 250 nurses working in hospital services and accepting to participate in the study. As a data collection tool; Information Form, Internet Addiction Scale (IAS) and Time Management Scale (TMS) were used.

Results: The mean age of the nurses was $32.56 \pm 8.19,72.8 \%$ of them were women, $55.0 \%$ were married, and $57.1 \%$ were undergraduate. It was found that $52.4 \%$ of nurses were using the time at medium level, $44.0 \%$ of them spent less than 10 hours/week on the internet. Internet Addiction Scale and its sub-dimensions; deprivation, difficulty in control, impairment in functionality, social isolation, respectively, 26.51 $\pm 9.38,18.96 \pm 7.53,12.51 \pm 5.84,11.40 \pm 5.15$ and 69.66 \pm 24.43 . Time Management Scale and its sub-dimensions; The mean averages of time planning, time attitudes, time wasters, and total time management scales were 49.25 $\pm 10.97,23.46 \pm 4.25,13.20 \pm 3.28,86.00 \pm 14.79$, respectively, were found. The correlations between the TMS and its sub-dimensions of the nurses and the IAS and sub-dimensions were middle, negative and significant.
} 
Conclusion: A negative and middle relationship was found between the mean scores of nurses' IAS and TMS. It can be suggested to increase the number of samples and to carry out studies in different groups.

Keywords: Nursing, internet addiction, time, time management

\section{Giriş}

İnternet Bağımlılı̆̆ı; "patolojik internet kullanımı", "problemli internet kullanımı", "aşırı internet kullanımı", "internet/net deliliğì" ve "internet bağlılığı" gibi farklı şekillerde de ifade edilmektedir [1,2]. Dünya'da 2018 yılının 2. Çeyreği verilerine göre, internet, sosyal medya ve mobil kullanıcısı 4,08 milyar, sosyal medya kullanıcısı 3.29 milyar ve mobil kullanıcısı 5.06 milyar bulunmaktadır [3]. Türkiye İstatistik Kurumu (TÜİK 2018) verilerine göre bilgisayar ve internet kullanımı, 1674 yaş grubundaki kişilerde \%59,6-72,9 ve evden internete erișim imkânının \%83,8 olduğu bildirilmiştir [4]. Türkiye'de internet kullanıcılarının ortalama 7 saat/günde internette ve 2 saat 48 dakika/günde ise sosyal medyada geçirdikleri saptanmıştır [5].

İnternet bağımlılı̆̆ 1 , internetin aşırı kullanılması isteğinin engellenememesi, internete bağlı olmadan geçirilen zamanın önemsiz hissedilmesi, yokluğunda aşırı sinirlilik, saldırganlık olması ve kişinin iş, sosyal ve ailevi hayatının giderek bozulması olarak tanımlanmaktadır [6,7]. İnternet bağımlılığında, internette uzun zaman geçirilmesi, internetten uzaklaşıldığında mutsuz olunması, yakın çevreye ayrılan zamanın azalması ve sosyal hayatın olumsuz etkilenmesi gibi genel belirtiler ortaya çıkmaktadır. Kişi, internetten iletişim kurduğu insanları, gerçek yaşamdaki insanlarla değişebilmektedir. Kişi belli bir süre çevreyle iletişim kuramadığ 1 için suçluluk hissedebilmekle birlikte internet kullanım süresi ve nedeniyle ilgili yalan söyleyebilmektedir $[1,8,9]$.

İnternet bağımlılığının zararları; ruhsal, sosyal, bedensel, akademik ve mesleki sorunlar şeklinde sıralanmaktadır. Bağımlılık derecesine göre, sağlık sorunlarının yanında mesleki, okul yaşamında aksaklıklar ve zamanı yönetememe vb. şeklinde problemler görülmektedir $[10,11]$. Ayrıca bağımlı kullanıcıların yalnızlık hissi, duygusal bozukluklar, düşük özgüven ve dürtüsel davranışlar gösterdiği bildirilmiştir [12]. Bağımlı kişilerin 40 saat/haftada internet kullandığı düşünülürse, bireyin uzun süre aynı pozisyonda kalması; kas, iskelet, sinir sistemi gibi birçok yapıyı etkilemektedir [13]. İnternet bağımlılığı, çalışma yaşamında da performans, etkinlik, verimlilik ve başarıyı düşürebilmektedir $[13,14]$.

İnternet kullanımı gereksiniminin ortaya çıkmasında, sosyalleşme ihtiyacı, en temel neden olarak ileri sürülmektedir. Ayrıca internetin e-posta, alışveriş, sohbet etme, oyun oynama ve forumlarda iletişime geçmek için kullanıldığ 1 da belirlenmiştir $[15,16]$. Başka bir çalışmada, internet bağımlısı olan bireylerin internet kullanım süresinin daha fazla olduğu ve diğer kişilerle etkileşim amaçlı kullandıkları görülmüştür [17]. İnternet bağımlılığı ile ilgili çalışmalar bu bağımlılığın hızlı bir şekilde yaygınlaştığını göstermektedir [18]. İnternet kullanan 531 öğrenci üzerinde yapılan başka bir çalışmada, internette geçirilen zaman ortalaması 8,1 saat/hafta olarak bulunmuştur [19].

Yapılan bir çalışmada, erkek hemşirelerin, 35 yaş altında olanların, serviste internet kullananların ve internette bir saatten fazla zaman geçirenlerin diğerlerine göre internet bağımlılığı ölçeğinden aldığı puan daha yüksek bulunmuştur [20]. Günümüzde insanların en çok zamanlarını alan faktörün internet olduğu belirlenmiştir. İnternet bağımlılığı sebebiyle zamanını doğru kullanamamaya bağlı sorunlar; stres ortaya çıkabilmektedir [21].

Zaman, tarih boyunca insanların önemini vurguladıkları bir kavramdır [22]. TDK'ya göre zaman; "bir işin, bir oluşun içinde geçtiği, geçeceği veya geçmekte olduğu süre, vakit" ve "belirlenmiş olan an" olarak geçmektedir [23].

Kişilerin bireysel ve mesleki yaşamını programlamasına yardımcı olacak en önemli şey zamanın etkin kullanımıdır. Zamanı etkin kullanma, bireyin iş hayatı, sosyal çevre ve ailesine ayrılacak zamanı dengeleme yöntemidir [23,24].

Hemşirelik mesleğinde de mesleki gereklilikler için interneti kullanmanın yanı sıra akıllı telefonların yaygınlaşmasıyla çalışma yaşamında bile sosyal paylaşım sitelerinde çok fazla zaman geçirildiği bilinmektedir. $\mathrm{Bu}$ durum çalışanların performans, verimlilik ve hizmet kalitesini belli düzeylerde etkileyebilmektedir. Bunun yanı sira, internet kullanımındaki sapmalar, zaman yönetimi sürecini de etkilemektedir [24-26].

Zamanı iyi yönetmek, işlerin hangilerinin öncelikli yapılacağını tespit edip yapmaktır [27]. Zaman yönetimi sürecinde [28]; bir işin ertelenmesini önlemeye yönelik tedbirler, kişisel verimi yükseltmek için kişisel değerler ve zaman kullanımıyla ilgili faydalı tekniklerin belirlenmesi önerilmektedir [29,30]. Zaman yönetimi süreci; zaman kullanımını analiz etme, zaman problemlerini tanımlama, kendini tanımlama, amaç, hedef ve öncelikleri belirleme, program hedeflerini uygulama planlarına aktarma, günlük plan ve programlar hazırlama, zaman yönetimi tekniklerini geliştirme, süreci analiz etme ve yeniden izleme aşamalarından oluşur [2731]. Boduç çalışmasında, araştırmaya katılan hemşirelerin çoğunluğunun zamanlarını orta düzeyde kullandıklarını belirlemiştir [32].

$\mathrm{Bu}$ çalışma, hemşirelerin internet kullanımı ile ilgili algıları, internet bağımlılı̆̆ düzeyleri ve zamanlarını kullanma durumları ile ilişkisini belirlemeye yöneliktir. Literatüre bakıldığında hemşirelerde internet bağımlılığ ve zaman yönetimi ilişkisinin ele alındığı çalışmaların eksikliği sebebiyle yaptığımız çalışma ileride yapılacak çalışmalar için altyapı oluşturması açısından önemlidir.

\section{Materyal Metot}

Araştırma, hemşirelerde internet bağımlılığı ve zaman yönetimi ilişkisinin belirlenmesi amacıyla tanımlayıcı ve 
kesitsel olarak gerçekleştirildi. Araştırma, Sağlık Bilimleri Üniversitesi Tepecik Eğitim ve Araştırma Hastanesi (SBÜTEA)'nde 15.04.2018 - 15.10.2018 tarihleri arasında yapıldı. Araştırmanın evrenini, SBÜTEA Hastanesinde çalışan hemşireler oluşturdu (750 hemşire). Araştırmanın örneklemini çalışmaya katılmayı kabul eden 250 hemşire oluşturdu. Araştırmanın yapıldığ 1 tarihlerde hastanede bulunan hemşirelere ulaşıldı. Kurumda hemşire olarak çalışmayan, polikliniklerde çalışan, raporlu, izinli, başka yerlerde görevli hemşireler araştırmaya dahil edilmedi. Veri toplama arac1 olarak; Bilgi Formu, İnternet Bağımlılığı Ölçeği (İBÖ) ve Zaman Yönetimi Anketi (ZYA) kullanıldı.

Bilgi Formunda, hemşirelerin tanıtıcı özelliklerini içeren; yaş, medeni durumu, görev, çalışma süresi, zamanı kullanma durumu, internet kullanma durumu, interneti kullanma ve zamanını değerlendirme ile ilgili 14 soru yer ald1.

\section{Internet Bă̆ımlıllı̆ğ Ölçeği (iBBÖ)}

Ölçeğin Türkçe uyarlaması 2010 yılında Selim Günüç tarafından yapılmıştır. Ölçek, beşli likert tipinde, 35 maddeden oluşmaktadır. Likert tipindeki derecelendirmeler; "Tamamen katıliyorum", "Katılıyorum", "Kararsızım", “Katılmıyorum", "Kesinlikle katılmıyorum" şeklindedir. Ölçek maddeleri 5'ten 1'e doğru puanlandırılmış olup, "Tamamen katıliyorum" derecesi 5 puan ile değerlendirilirken "Kesinlikle katılmiyorum" derecesine 1 puan denk gelmektedir. Yani madde puanları 1'den 5'e doğru arttıkça bağımlılık düzeyi de artmaktadır. Ölçeğin orijinaline ilişkin iç tutarlılık katsayısını 0.95 iken bu çalışmada 0,97 olarak belirlenmiştir. Ölçek dört alt boyuttan oluşmaktadır. Bu dört faktör; "Yoksunluk", "Kontrol Güçlüğü", "İşlevsellikte Bozulma" ve "Sosyal İzolasyon” olarak adlandırılmıştır (33).

\section{Zaman Yönetimi Anketi (ZYA)}

Britton ve Tesser'in (1991) beraber geliştirdikleri Zaman Yönetimi Anketi (ZYA)'nin Türkçe geçerlilik ve güvenilirliği Alay ve Koçak (2002) tarafından yapılmıştır. Ölçek, 27 maddeden oluşmaktadır; zamanı planlama, zaman tutucular ve zaman harcattırıcılar olmak üzere üç alt boyutu vardır. Ölçek 5'li likert kullanılarak değerlendirilmiştir. "Zamanı planlama" alt boyutunda 16, "Zaman tutucular" alt boyutunda yedi ve "Zaman harcattırıcılar" alt boyutunda ise dört ifade yer almaktadır. Kişilerin zaman yönetimi ile ilişkili pozitif ifadelere verdikleri yanıtlar; "Her zaman" (5 puan), "Sik sık" (4 puan), "Bazen" (3 puan), "Nadiren" ( 2 puan) ve "Hiç" (1 puan) şeklinde puanlanmıştır. Ölçekte 22, 24, 25,26 ve 27 . maddeler ters kodlanan ifadeler olup puanlaması ters şekilde yapılmıştır. Ölçeğin orjinalinde Türkçe formunun Cronbach alfa katsayısı tüm ölçek için 0.87 , zamanı planlama 0,88 , zaman tutucular 0,66 ve zaman harcattırıcılar alt boyutunda ise 0,47 olarak bulunmuştur [34]. Ölçeğin genelinde ve alt boyutlarında bulunan sonuçların yüksekliği, kişinin zamanı yönetme becerisinin yüksekliğini gösterirken sonuçların düşmesi ise zaman yönetiminin iyi olmadığı şeklinde değerlendirilmektedir.

Araştırmanın verileri, SPSS 23.0 (SPSS, Inc., Chicago, IL, USA) İstatistik paket programında değerlendirildi. Veri analizinde sayı, yüzde, ortalama, standart sapma olmak üzere tanımlayıcı istatistiklerden yararlanıldı. Tanımlayıcı özelliklere ilişkin kategoriler arasında ölçek alt boyutları ve toplam puan ortalamalarının karşılaştırılmasında, normal dağılıma uyan verilerde $\mathrm{T}$ testi ve tek yönlü varyans analizi (Anova), normal dağılıma uymayan verilerde ise Mann Whitney U ve Kruskal Wallis Testi kullanıldı. İBÖ ile ZYA toplam ve alt boyutları arasındaki ilişkinin değerlendirilmesinde Spearman Korelasyon analizinden yararlanıldı.

Manisa Celal Bayar Üniversitesi Sağlık Bilimleri Etik Kurulundan etik onay, çalışmayı yapabilmek için İzmir Il Sağlık Müdürlüğü'nden ve araştırmaya katılan hemşirelerden onay alındı.

\section{Bulgular}

Tablo 1'de araştırmaya katılan hemşirelerin yaş ortalaması $32,56 \pm 8,19, \% 42,8$ 'i 20 - 29 yaş, \%72,8'i kadın, \%56,0'^1 evli, \%56,0'sı lisans, \%88,4'ü hemşire olarak çalışmakta, \%35,2'si 5- 10 yil arası mesleki deneyime sahip, \%57,2'si 5 y1ldan daha az kurumda çalışmaktadır.

Tablo 1. Hemşirelerin Tanımlayıcı Özellikleri ( $\mathrm{n}=250)$

\begin{tabular}{|c|c|c|}
\hline Tanımlayıcı Özellikler & Sayı (n) & Yüzde (\%) \\
\hline \multicolumn{3}{|l|}{ Yaş Grupları (X $\pm \mathrm{SS}: 32,56 \pm 8,19)$} \\
\hline $20-29$ yaş & 107 & 42,8 \\
\hline $30-39$ yaş & 90 & 36,0 \\
\hline$\geq 40$ yaş & 53 & 21,2 \\
\hline \multicolumn{3}{|l|}{ Cinsiyet } \\
\hline Kadın & 182 & 72,8 \\
\hline Erkek & 68 & 27,2 \\
\hline \multicolumn{3}{|l|}{ Medeni Durum } \\
\hline Evli & 140 & 56,0 \\
\hline Bekar & 110 & 44,0 \\
\hline \multicolumn{3}{|l|}{ Eğitim Durumu } \\
\hline Sağlık Meslek Lisesi & 50 & 20,0 \\
\hline Önlisans & 40 & 16,0 \\
\hline Lisans & 140 & 56,0 \\
\hline Lisansüstü & 20 & 8,0 \\
\hline \multicolumn{3}{|l|}{ Hastanedeki Görevi } \\
\hline Hemşire & 221 & 88,4 \\
\hline Yönetici Hemşire & 29 & 11,6 \\
\hline \multicolumn{3}{|l|}{ Meslekte Çalışma Süresi } \\
\hline$(\mathrm{X} \pm \mathrm{SS}: 10,20 \pm 7,51 \mathrm{y} 1 \mathrm{l})$ & 69 & 27,6 \\
\hline$<5$ y1l & 88 & 35,2 \\
\hline $5-10$ yil & 33 & 13,2 \\
\hline $11-15$ y1l & 60 & 24,0 \\
\hline \multicolumn{3}{|l|}{16 yil ve üzeri } \\
\hline \multicolumn{3}{|l|}{ Kurumda Çalışma Süresi } \\
\hline$(\mathrm{X} \pm \mathrm{SS}: 6,16 \pm 5,88 \mathrm{y} 1 \mathrm{l})$ & 143 & 57,2 \\
\hline$<5$ y1l & 64 & 25,6 \\
\hline $5-10$ yil & 20 & 8,0 \\
\hline $11-15$ y1l & 23 & 9,2 \\
\hline 16 yıl ve üzeri & & \\
\hline
\end{tabular}

Hemşirelerin internet kullanma durumlarının $\% 52,4$ 'ünün orta düzeyde olduğunu düşündüğü, $\% 57,2$ 'sinin cep telefonu ve \%52,0'sinin evde internete girdiği, \%44,0'ının 10 saatten az/haftada internet kullandığ1, \%80,0’1 sosyal paylaşım sitelerine girmek 
amacıyla internet kullandığını, \%92,0'ının sosyal paylaşım ağlarında hesabı olduğu ve \%82,4'ünün internet kullanımının günlük işleri aksatmadığını düşündükleri saptandı (Tablo 1).

Tablo 2'de Hemşirelerin İBÖ, ZYA ve alt boyutlarından aldıkları puan ortalamaları yer almaktadır.

Tablo 2. Hemşirelerin İnternet Bağımlılı̆̆ı Ölçeği, Zaman Yönetimi ve Alt Boyutları Puan Ortalamalarının Dağılımı

\begin{tabular}{|c|c|c|c|}
\hline $\begin{array}{c}\text { Ölçekler alt } \\
\text { boyutları }\end{array}$ & $\mathrm{X} \pm \mathrm{SS}$ & Min-Maks & $\begin{array}{l}\text { Puan } \\
\text { aralığı }\end{array}$ \\
\hline $\begin{array}{l}\text { İBÖ Alt } \\
\text { Boyutları } \\
\text { Yoksunluk }\end{array}$ & $26,51 \pm 9,38$ & $11,00-50,00$ & $11,00-55,00$ \\
\hline Kontrol güçlüğü & $18,96 \pm 7,53$ & $10,00-50,00$ & $10,00-50,00$ \\
\hline $\begin{array}{l}\text { İşlevsellikte } \\
\text { bozulma }\end{array}$ & $12,51 \pm 5,84$ & $7,00-35,00$ & $7,00-35,00$ \\
\hline Sosyal izolasyon & $11,40 \pm 5,15$ & $7,00-35,00$ & $7,00-35,00$ \\
\hline TOPLAM & $69,66 \pm 24,43$ & $35,00-157,00$ & $\begin{array}{l}35,00- \\
175,00\end{array}$ \\
\hline $\begin{array}{l}\text { ZYA Alt } \\
\text { Boyutları } \\
\text { Zaman } \\
\text { planlaması }\end{array}$ & $49,25 \pm 10,97$ & $19,00-80,00$ & $16,00-80,00$ \\
\hline Zaman tutumları & $23,46 \pm 4,25$ & $12,00-34,00$ & $7,00-35,00$ \\
\hline $\begin{array}{l}\text { Zaman } \\
\text { harcattırıcılar }\end{array}$ & $13,20-3,28$ & $5,00-20,00$ & $4,00-20,00$ \\
\hline TOPLAM & $86,00 \pm 14,79$ & $48,00-129,00$ & $\begin{array}{l}27,00- \\
135,00\end{array}$ \\
\hline
\end{tabular}

Tablo 3'te, İBÖ ile ZYA ve alt boyutları arasındaki korelasyon düzeyleri görülmektedir. İBÖ "Yoksunluk", "Kontrol güçlüğü", "İşlevsel Bozulma" boyutu ile ZYA "Zaman planlaması" boyutu arasında zayıf negatif ve anlaml,, İBÖ ve "Sosyal İzolasyon" boyutu ile ZYA "Zaman planlaması" boyutu arasında çok zayıf, negatif ve anlamlı, İBÖ ve "Yoksunluk", "Kontrol güçlüğü" ve "İşlevsel bozulma" alt boyutları ile ZYA "Zaman tutumu" boyutu arasinda orta, negatif ve anlaml, İBÖ "Sosyal izolasyon" boyutu ile ZYA "Zaman tutumu" boyutu arasında zayıf negatif ve anlamlı, İBÖ ile ZYA "Zaman tutumu" boyutu arasinda orta, negatif ve anlaml, İBÖ "Yoksunluk" boyutu ile ZYA "Zaman harcattırıcılar" boyutu arasında çok zayıf, negatif ve anlaml, İBÖ ve "Kontrol güçlüğü", "İșlevsel bozulma", "Sosyal izolasyon" boyutları ile ZYA "Zaman harcattırıcılar" boyutu arasında çok zayıf, negatif ve anlaml, İBÖ "Yoksunluk", "İşlevsel bozulma" boyutları ile ZYA toplam puanı arasında orta, negatif ve anlamlı ve İBÖ "Kontrol güçlüğü", "Sosyal izolasyon" boyutu ile ZYA arasında zayıf, negatif ve anlamlı bir ilişki olduğu belirlendi (Tablo 3). Hemşirelerin sosyodemografik özellikleri ile İBÖ ve ZYA alt boyutları arasında ilişki incelendiğinde; Hemşirelerin yaş grupları ve eğitim durumları ile İBÖ toplam puan ve alt boyutları,

Tablo 3. Hemşirelerin İBÖ ve ZYA Toplam ve Alt Boyutları Arasındaki Korelasyonlar

\begin{tabular}{|c|c|c|c|c|c|}
\hline $\begin{array}{l}\text { ZYA } \\
\text { İBÖ }\end{array}$ & & $\begin{array}{l}\text { Zaman } \\
\text { Planlaması }\end{array}$ & $\begin{array}{l}\text { Zaman } \\
\text { Tutumu }\end{array}$ & $\begin{array}{l}\text { Zaman } \\
\text { Harcattırıcılar }\end{array}$ & $\begin{array}{l}\text { Zaman } \\
\text { Yönetimi }\end{array}$ \\
\hline Yoksunluk & $\begin{array}{l}\mathrm{r} \\
\mathrm{p}\end{array}$ & $\begin{array}{l}-0,255\left(^{*}\right) \\
0,000\end{array}$ & $\begin{array}{l}-0,423(* *) \\
0,000\end{array}$ & $\begin{array}{l}-0,143(*) \\
0,029\end{array}$ & $\begin{array}{l}-0,333(* *) \\
0,000\end{array}$ \\
\hline $\begin{array}{l}\text { Kontrol } \\
\text { Güçlüğü }\end{array}$ & $\begin{array}{l}\mathrm{r} \\
\mathrm{p}\end{array}$ & $\begin{array}{l}-0,233\left({ }^{*}\right) \\
0,000\end{array}$ & $\begin{array}{l}-0,340(* *) \\
0,000\end{array}$ & $\begin{array}{l}-0,167(*) \\
0,010\end{array}$ & $\begin{array}{l}-0,299 \text { (**) } \\
0,000\end{array}$ \\
\hline $\begin{array}{l}\text { İşlevsel } \\
\text { Bozulma }\end{array}$ & $\begin{array}{l}\mathrm{r} \\
\mathrm{p}\end{array}$ & $\begin{array}{l}-0,221(*) \\
0,001\end{array}$ & $\begin{array}{l}-0,352(* *) \\
0,000\end{array}$ & $\begin{array}{l}-0,174(*) \\
0,006\end{array}$ & $\begin{array}{l}-0,304(* *) \\
0,000\end{array}$ \\
\hline $\begin{array}{l}\text { Sosyal } \\
\text { İzolasyon }\end{array}$ & $\begin{array}{l}\mathrm{r} \\
\mathrm{p}\end{array}$ & $\begin{array}{l}-0,175(*) \\
0,008\end{array}$ & $\begin{array}{l}-0,263(*) \\
0,000\end{array}$ & $\begin{array}{l}-0,187(*) \\
0,003\end{array}$ & $\begin{array}{l}-0,250(*) \\
0,000\end{array}$ \\
\hline $\begin{array}{l}\text { İnternet } \\
\text { Bağımlılığ1 }\end{array}$ & $\begin{array}{l}\mathrm{r} \\
\mathrm{p}\end{array}$ & $\begin{array}{l}-0,253(*) \\
0,000\end{array}$ & $\begin{array}{l}-0,414(* *) \\
0,000\end{array}$ & $\begin{array}{l}-0,182(*) \\
0,006\end{array}$ & $\begin{array}{l}-0,338(* *) \\
0,000\end{array}$ \\
\hline
\end{tabular}

zaman tutumları, zaman harcattırıcılar arasında anlamlı fark görülmedi. Hemşirelerin cinsiyet ile İBÖ toplam ve alt puan ortalamaları arasında anlamlı farklar bulundu $(p<0,05)$. İBÖ alt boyutlarında erkeklerin puan ortalamaları kadınların puan ortalamalarından daha yüksekti. Çalışmada kadınların ZYA “Zaman harcattırıcılar" boyutu hariç diğer boyutlarında anlamlı farklar bulundu $(\mathrm{p}<0,05)$ ve kadınların zaman yönetimi puanları daha yüksekti. Hemşirelerin medeni durumları ile IBÖ alt boyutlarından; yoksunluk alt boyutuyla anlamlı fark görüldü $(\mathrm{p}<0,05)$. Hemşirelerin medeni durum ile ZYA toplam ve alt boyutları arasında anlamlı bir ilişki bulunmadı. Hemşirelerin hastanedeki görevi ile İBÖ ve alt boyutları puan ortalamaları arasında anlamlı fark yoktu. ZYA ve alt boyutlarından; zaman planlaması, zaman harcattırıcılar ve ZYA toplam puan arasında anlamlı farklar görüldü $(\mathrm{p}<0,05)$. Yönetici hemşirelerin puan ortalamaları hemşirelere göre anlamlı olarak daha yüksek bulundu.

Hemşirelerin meslekte çalışma yılı ile İBÖ alt boyutlarından; yoksunluk arasında anlamlılı vardı. Hemşirelerin meslekte çalışma süreleri ile ZYA alt boyutlarından; zaman planlaması, zaman tutumları ve toplam puan arasında anlamlı fark görülmezken zaman harcattırıcılar alt boyutuyla anlamlı fark görüldü $(p<0,05)$. Hemşirelerin zaman kullanımına ilişkin görüşlerine göre, İBÖ ve alt boyutları puan ortalamalarının arasında anlamlı fark görülmedi $(p>0,05)$. ZYA zaman planlaması, zaman tutumları ve toplam puanları arasında anlamlı farklar bulundu $(\mathrm{p}<0,05)$.

Hemşirelerin haftalık internet kullanım süresi ile İBÖ toplam ve alt boyutları arasinda, internet hesabı olan hemşirelerin İBÖ yoksunluk, kontrol güçlügüü, 
işlevsellikte bozulma ve toplam puan ortalamaları arasında da anlamlı farklar belirlendi $(\mathrm{p}<0,05)$.

\section{Tartışma}

Bu çalışmada, İBÖ ve ZYA toplam puan ve alt boyut ortalamaları ile ilgili bulgular tartışıldı. Çalışmada, İBÖ toplam puan ortalamas1 $69,66 \pm 24,43$ olarak bulundu. Elde edilen bu ortalama, eşik değerin biraz üstünde yer almakla birlikte standart sapmanın yüksek olması dolayısıyla çalışmaya katılan hemşirelerin İBÖ toplam puan ortalaması, internet bağımlılı̆̆ eşik değerinde bulunmaktadır. Günüç'ün İBÖ toplam puan üzerinden yaptığı bağımlılık gruplamasına göre $67,00 \pm 5,98$ eşik değer olarak belirlenmiştir [33]. Bu nedenle hemşirelerin internet bağımlılığı düzeyine gelmeden gerekli önlemler alınması önemlidir.

Hemşirelerin ZYA puan ortalaması ise $86,00 \pm 14,79$ olarak bulundu. Ölçekte alınabilecek toplam puan 27 ila 135 arasında değişmekte olup [34] hemşirelerin aldığı puan ortalamasının yüksek olduğu; diğer bir ifadeyle hemşirelerin zamanlarını iyi yönettikleri söylenebilir. Hemşirelerin eğitim müfredatlarında zaman yönetimine ilişkin dersler almış olmaları ve hizmet içi eğitimleri sırasında zaman yönetimi konularını ele almış olmalarının sonucu etkilediği düşünülebilir.

Hemşirelerin yaş grupları ve eğitim durumları ile İBÖ alt boyutları ile ZYA alt boyutları arasında da anlamlı fark görülmedi. Üçkardeş ve Şahin'in çalışmalarında da internet bağımlılığı puanları ile yaş grupları ortalamaları arasında fark bulunmamıştır $[35,36]$. Soydan yaptığ çalışmada, internet bağımlılığı ile yaş değişkeni arasında zayıf ve negatif yönlü bir ilişki bildirmiştir [37] Greenfield (1999), internet bağımlılığının genç erişkinlerde daha sık görüldüğünü belirtmiştir [38]. Hemşirelerin yaş grupları ile ZYA toplam puanı arasında anlamlı fark belirlendi; 40 yaş ve üzeri hemşirelerin puan ortalaması diğer gruplara oranla daha yüksekti.

Yaş arttıkça deneyim artacağından zamanı yönetebilme yeteneği de artmaktadır. Bu sonuç, Başak ve ark.'nın ve Sarp ve ark.'nın yaş ile zaman yönetimi davranışları arasında bir ilişki olduğunu gösteren çalışmalarla uyumludur [39,40]. Uyanıker (2014) çalışmasında, hemşirelerin yaşlarının arttıkça zaman yönetimi konusunda daha başarılı olduklarını tespit etmiştir [41]. Hemşirelerin cinsiyet ile İBÖ alt boyutları ve toplam puan ortalamaları arasında; erkeklerin puan ortalamaları kadınların puan ortalamalarından anlamlı olarak daha yüksekti. Balcı ve ark. üniversite öğrencilerinin (440 öğrenci) katıldığı çalışmada, erkeklerin kadınlara göre daha fazla internette zaman geçirdikleri bulunmuştur. Ayrıca, üniversite öğrencilerinin günlük internet kullanım süresi arttıkça internet bağımlılığı düzeyinin de arttığ1 saptanmıştır [42]. Özcan'ın çalışmasında, erkeklerin puan ortalaması kadınlara göre istatistiksel olarak yüksek görülmüştür [43]. Balta ve Horzum'un çalışmasında, erkek öğrencilerin internet bağımlılığı puan ortalaması kız öğrencilere göre daha yüksek bulunmuştur [44]. İşsever, erkek olmanın internet bağımlılığ 1 için risk faktörü olduğu sonucuna ulaşmıştır [45]. Tetik'in çalışması ile çalışmamızın bulguları paralellik göstermektedir; erkeklerin puan ortalaması kadınlara göre daha yüksek bulunmuş ve bunun sebebinin cinsiyet arası genetik ve bilişsel farklılık olabileceği ifade edilmiştir [46]. Griffiths yaptığı çalışmada, internet bağımlılığının kadınlarda daha sık görüldüğünü belirtmiştir [47]. Çalışmada kadınların ZYA "Zaman harcattırıcılar" boyutu hariç diğer boyutlarında anlamlı farklar bulundu ve kadınların zaman yönetimi puanları daha yüksekti. Kadınların sosyal hayat, ev ile iş arasında bir denge kurmaya çalıştığı düşünüldüğünde, kadınların zaman yönetimi konusunda daha başarılı olduğu söylenebilir. Yüksel (2016)'in çalışmasında zaman yönetiminde cinsiyetin etkisiz olduğu görülmüştür [48].

Hemşirelerin medeni durumları ile İBÖ alt boyutlarından; yoksunluk alt boyutuyla anlamlı fark görüldü. Bekar hemşirelerin puan ortalaması evli hemşirelere göre anlamlı olarak daha yüksekti. Sancar (2017) yaptığ $\breve{1}_{1}$ çalıșmada, sözlü/nişanlıların internet kullanma oranı daha yüksek çıkmıştır [49]. Hemşirelerin medeni durum ile ZYA alt boyutları arasında anlamlı bir ilişki bulunmadı. Evlilerin puan ortalaması, bekarlara göre anlamlı düzeyde yüksekti. Uyanıker'in medeni durum ile zaman yönetimi davranışları arasında bir ilişki olduğunu gösteren çalışması ile uyumsuz [41], Kıdak'ın (2011) çalışmasıyla da uyumludur [50].

Hemşirelerin eğitim durumları ile İBÖ ve ZYA toplam ve alt boyutları arasında anlamlı farklar görülmemesinin yanında lisansüstü eğitim alan hemşirelerin zaman yönetimi puan ortalamaları daha yüksekti. Hemşirelerin lisansüstü eğitimlerinin kapsamında zaman yönetimine yönelik konuların ele alındığı ve ilgili konuların hemşirelerin bilinçlenmelerini sağladığ 1 söylenebilir. Bahçecik ve ark. (2004)'ının ve Karasu (2015)'nun ve Ebrahimi ve ark. (2014)'ının çalışmalarında da benzer sonuçlar elde edilmiştir [26,27,51].

$\mathrm{Bu}$ çalışmada yönetici hemşirelerin puan ortalamaları hemşirelere göre anlamlı olarak daha yüksek bulundu. Yönetici hemşirelerin zamanlarını yönetme konusunda daha iyi bilgi ve deneyime sahip oldukları düşünülmektedir. Yönetici hemşirelerin zaman yönetimi konusunda daha bilinçli oldukları ve zamanları yönetmek konusunda çaba gösterdikleri şeklinde yorumlanabilir. Sarp ve ark.'nın (2005) çalışmalarında da benzer sonuca varılmıştır [40]. Yönetici hemşirelerin günlük, haftalık ya da aylık programlar yapıp uygulamaya yöneltmeleri nedeniyle zamanı daha etkili kullanmaya yönelik tutum ve davranışları geliştirmektedirler.

Hemşirelerin haftalık internet kullanım süreleri ile İBÖ toplam ve alt boyutları ortalamaları arasında anlamlı ilişki tespit edildi ve haftalık 21 saat ve daha fazla internet kullananlarda puan ortalamaları daha yüksekti. Haftalık internet kullanım süresi yüksek olanların internet bağımlılığı puan ortalamalarının yüksek olması beklenen bir durumdur ve literatürde de benzer sonuçlar bulunmaktadır. Chen (1998) internet bağımlılarının haftada 19 saat, Chou ve Hsiao (2000) ise haftada 20-25 saat internet kullandıklarını bildirmişlerdir [52,53]. Hardie ve Tee, bağımlı olmayan kişilerin interneti ortalama 21,84 saat/hafta, bağımlı kullanıcıların ise 
ortalama 68,88 saat/hafta kullandıklarını bulmuştur [54]. Günüç’ün bildirdiğine göre, Simkova ve Cincera bağımlı olmayan bireylerin ortalama 13 saat/hafta ve bağıml bireylerin ortalama 44 saat/hafta internet kullandığını tespit etmişlerdir [33]. Tahiroğlu ve arkadaşlarının (2008) yaptığ çalışmada, 12-18 yaş grubundaki ergenler arasında 12 saat/hafta üzerinde internet kullanımı \% 7,6 olarak belirlenmiştir [55]. Kelleci ve arkadaşlarının lise öğrencileri üzerinde yaptıkları çalışmada, kız öğrencilerin \%70,2'sinin, erkek öğrencilerin \%60,2'sinin günde 1- 2 saat internet kullandıkları saptanmıştır [56]. $\mathrm{Bu}$ sonuçlar incelendiğinde, farklı çalışmalarda farklı internet kullanım miktarları gözlenmektedir. Ancak bu çalışmalarda ortak sonuç, bağımlı bireylerin internet kullanım süresinin bağımlı olmayan bireylere göre dikkate değer ölçüde fazla olmasıdır [33].

Ayrıca daha önce yapılmış çalışmalarda internet kullanımı güncel değerlerle karşılaştırıldığında oldukça düşüktür; bu sonuçlarla birlikte her geçen gün internet kullanımının arttığı söylenebilir. Hemşirelerin haftalık internet kullanım saatine göre; 10 saat ve daha az internet kullanan hemşirelerin zamanlarını daha iyi yönettikleri görülmektedir. Hemşirelerin zaman kullanımına ilişkin görüşleri ile ZYA ve alt boyutlarından; zaman planlaması, zaman tutumları ve ZYA toplam puan ortalamaları arasında anlamlı farklar görüldü. Zaman kullanımını iyi olarak ifade edenlerin puan ortalaması, orta ve zayıf olarak ifade edenlere göre daha yüksek bulundu. Zaman yönetiminin iyi olduğunu düşünen hemşirelerin ZYA puan ortalamalarının da yüksek olmasının zaman yönetimi farkındalığıyla ilişkili olduğu düşünülmektedir.

Hemşirelerin sosyal paylaşım hesabı olma durumu ile İBÖ toplam ve alt boyut puan ortalamaları arasında anlamlı farklar bulunmaktadır ve bu tesadüf değildir. Sosyal paylaşım sitelerinde hesabın olmasının internete girme ve hesabında paylaşılanları takip etme isteğini arttıracaktır. Tsimtsiou ve arkadaşlarının yaptığ çalışmaya göre, sosyal medya kullananlarda internet bağımlılığı düzeyi anlamlı olarak yüksek çıkmıştır [57]. Turan'ın bildirdiğine göre, Ak ve arkadaşlarının yaptığ bir çalışmada, sosyal medya kullanımı ve çevrimiçi oyun oynama durumu ile internet bağımlılığı düzeyi arasında anlamlı ilişki mevcuttur [58].

Çalışmada elde edilen bulgular çerçevesinde, İBÖ ile ZYA ve alt boyutları arasında zayıf, negatif ve anlamlı bir ilişki vardı. Köse ve arkadaşları üniversite öğrencileri üzerinde yaptıkları çalışmada, internet bağımlılığı ile zaman yönetimi arasında orta, negatif ve anlamlı ilişki tespit etmişlerdir [59]. İnternet bağımlılığı ile alt boyutları ve zaman yönetimi ile alt boyutları puan ortalamaları arasında anlamlı ve negatif yönde bir ilişki olmasına rağmen birçok boyutuyla zayıf ve orta düzeyde bir ilişki saptanması nedeniyle "H1-Hemşirelerde internet bağımlılı̆̆ ile alt boyutları ve zaman yönetimi ile alt boyutları arasında ilişki vardır." hipotezi kabul edilmiş oldu. İnternet bağımlılığı ve zaman yönetimi arasındaki ilişkinin boyutu ile ilgili başka örneklemlerde çalışılması gerekmektedir. Bu çalışmanın sonuçları, ilerleyen zaman içinde internet bağımlılı̆̆ durumlarının artacağı öngörüsüyle zaman yönetiminin de olumsuz etkileneceğine ilişkin ön değerlendirme olarak ele alınabilir.

\section{Sonuç}

Hemşirelerde internet bağımlılığı ve zaman yönetimi arasındaki ilişkinin incelendiği bu araştırmada;

Araştırma grubunda yer alan hemşirelerin yaş ortalaması 32,56 $\pm 8,19$, İBÖ alt boyutları puan ortalamalar1; "Yoksunluk" 26,51 $\pm 9,38$; "Kontrol güçlüğü" 18,96 $\pm 7,53$; "İşlevsellikte bozulma" $12,51 \pm 5,84$, "Sosyal izolasyon $11,40 \pm 5,15$ ve İBÖ puan ortalaması ise $69,66 \pm 24,43$ olarak bulundu. İBÖ toplam puan ortalaması, internet bağımlılığı eşik değerinde bulunmaktadır. ZYÖ alt boyut puan ortalamaları; "Zaman planlamas1" 49,25 $\pm 10,97$; "Zaman tutumlar1" $23,46 \pm 4,25$; "Zaman harcattıricilar" $13,20 \pm 3,28$ ve ZYA puan ortalamas 1se $86,00 \pm 14,79$ olarak saptand1. ZYA alt boyutları ve toplam puanları, orta düzeyin üstünde yer almaktadır. İBÖ ile ZYA toplam ve alt boyut puan ortalamaları arasında orta, negatif yönlü ve istatistiksel olarak anlamlı ilişkilerin olduğu belirlendi.

Araştırmadan elde edilen sonuçlar doğrultusunda;

- Hemşirelik eğitimi müfredatında internet bağımlılığı ve zaman yönetimine yönelik konuların yer almasının sağlanması,

- Hemşirelerin internet bağımlılı̆̆ ve zaman yönetimi konusunda farkındalıklarının artırılması için; bilinçli internet kullanımı ve zaman yönetimi hakkında bilgilendirilmesi, gerekli eğitimlerin planlanması ve danışmanlık yapılması,

- Hemşirelerin internet bağımlılık düzeylerinin azaltılması için sosyal etkinliklere teşvik edilmesi, hemşireler arası etkileşimlerin artırılması ve grup çalışmalarının planlanması,

- Erkeklerin İBÖ puan ortalamasının yüksek, ZYA puan ortalamasının düşük olması nedeniyle erkek hemşirelere yönelik internet bağımlılığı ve zaman yönetimi konusunda duyarlılık eğitimleri yapılması,

- İnternet bağımlılığ profesyonel yardım almak için yönlendirilmesi,

- Yönetici hemşirelerin zaman yönetimi ve zaman tuzakları hakkında bilgi sahibi olması, etkili kurum politikaları oluşturmaları ve hemşireleri bu konuda yönlendirmeleri ve

- Farklı örneklem grupları ve büyüklüklerinde hemşirelerin internet bağımlılık düzeyleri, nedenleri ve zaman yönetimi becerilerinin araştırılması önerilir.

Referanslar

1. Tsai, C, Lin, SJ, Analysis of attitudes toward computer networks and internet addiction of taiwanese adolescents. Cyberpsychology and Behavior, 2001, 4 (3),373- 376

2. Sonkur, A, İnternet bağımlılığının depresyon, tepki biçimleri, düșünce baskılama, endişe ve üst bilişle ilişkisi. Yüzüncü Y1l Üniversitesi Eğitim Bilimleri Enstitüsü Eğitim Bilimleri Anabilim Dalı Psikolojik Danışmanlık ve Rehberlik Bilim Dalı Yüksek Lisans Tezi. 2014.

3. https://dijilopedi.com/dunyada-internet-kullanimi-ve-sosyal-medyaistatistikleri-2-ceyrek-raporu/Erişim Tarihi: 02.09.2018

4. TÜiK Hanehalkı Bilişim Teknolojileri Kullanım Araştırması https://www.guvenliweb.org.tr/haber-detay/turkiyenin-internet-kullanimaliskanliklari-tuik-2018.(Erișim Tarihi: 08.08.2018).

5. https://www.igturkiye.com/guncel-internet-kullanimi-ve-sosyal-medyaistatistikleri-2018/ 
6. Shapira, NA, Lessig, MC, Goldsmith, TD, Szabo, ST, Lazoritz, M, et al. Problematic internet use: proposed classification and diagnostic criteria, Depression and Anxiety, 2003,17(4), 207-216.

7. Young, KS, Internet addiction: a new clinical phenomenon and its consequences, American Behavioral Scientist, 2004, 48,402-415.

8. Ögel, K, İnternet bağımlılığı, Türkiye İş Bankası Kültür Yayınları: İstanbul; 2012

9. Widyanto, L, Griffiths, M. Internet addiction: a critical review. International Journal of Mental Health and Addiction, 2006, 4, 31-51.

10. Caplan, SE, A social skill account of problematic internet use. The Journal of Communication, 2005, 55(4), 721-736.

11. Bolışık, B, Muslu, G, Çocuk ve gençlerde internet kullanımı. TAF Prev Med Bull, 2009, 8(5), 445-450.

12. Beranuy, M, Oberst, U, Carbonell, X, Chamarro, A, Problematic internet and mobile phone use and clinical symptoms in college students: the role of emotional intelligence, Computers in Human Behavior, 2009, 25(5), 1182 1187

13. Young, KS. Internet addiction: the emergence of a new clinical disorder CyberPsychology and Behavior, 1996, 1(3), 237-244.

14. Gönül, AS, Patolojik internet kullanımı (internet bağımlılı̆̆1 / kötüye kullanımı), Yeni Sempozyum Dergisi, 2002, 40(3),105-110.

15. Hur, MH, Demographic, habitual, and socioeconomic determinants of interne addiction disorder: an empirical study of Korean teenagers, CyberPsycholog \& Behavior, 2006 9(5), 514-525.

16. Hur, $\mathrm{MH}$, Current trends of internet addiction disorder research: a review of 2000-2008, Korean academic journal articles, Asia Pacific Journal of Socia Work and Development, 2012, 22(3),187-201.

17. Terzioğlu, B, İnternet bağımlılığının yordayıcıları olarak duygusal zeka ve kişilerarası problem çözme, İstanbul Arel Üniversitesi Sosyal Bilimle Enstitüsü Psikoloji Anabilim Dalı Psikoloji Programı Yüksek Lisans Tezi, 2017

18. Derin, S, Lise öğrencilerinde internet bağımlılığı ve öznel iyi oluş. Hacettep Üniversitesi Sosyal Bilimler Enstitüsü Eğitim Bilimleri Anabilim Dalı Yüksek Lisans Tezi, 2013

19. Kurtaran, G, İnternet bağımlılığını yordayan değişkenlerin incelenmesi. Mersin Üniversitesi Sosyal Bilimler Enstitüsü Eğitim Bilimleri Anabilim Dalı Yüksek Lisans Tezi, 2008.

20. Kaynak, S, Duran, S, Karadaș, A, Hemșirelerde internet bağımlılığı ve yalnızlık düzeyi arasındaki ilişkisinin belirlenmesi. Sağllk ve Hemşirelik Yönetim Dergisi, 2018, 1(5), 27-35.

21. Doğan, A, İnternet bağımlılı̆̆1 yaygınlığı, Dokuz Eylül Üniversitesi Eğitim Bilimleri Enstitüsü Aile Eğitimi ve Danıșmanlığı Anabilim Dalı Yüksek Lisans Tezi, 2013.

22. Yeşil, F, Hastane yöneticilerinin etkili zaman yönetimine ilişkin görüşlerinin incelenmesi. Yeditepe Üniversitesi Sağlık Bilimleri Enstitüsü Yüksek Lisans Tezi, 2009.

23. Şen M, Hemşirelik yüksekokulu öğrencilerinde zaman yönetiminin akademik başarıya etkisi. İstanbul Bilim Üniversitesi Sağlık Bilimleri Enstitüsü Hemşirelik Yüksek Lisans Programı Yüksek Lisans Tezi, 2014.

24. Akçinar S. Örgütsel zaman yönetimi ve etkin zaman kullanımı. Beyken Üniversitesi Sosyal Bilimler Enstitüsü İșletme Yönetimi Anabilim Dal Yönetim ve Organizasyon Bilim Dalı, Yüksek Lisans Tezi.2014.

25. Ançel, G, Hemşirelerde zamanı verimli kullanma. Hacettepe Üniversitesi Sağlık Bilimleri Enstitüsü Doktora Tezi, 1996.

26. Bahçecik, N, Yönetici hemşireler için zaman yönetimi ölçeği ve zaman yönetimini etkileyen faktörler, Yönetim Dergisi, 2004, (1),67-68.

27. Karasu, G, Yönetici hemşirelerde zaman yönetimin incelenmesi, Hali Üniversitesi Sağlık Bilimleri Enstitüsü Hemşirelik Anabilim Dalı Yüksek Lisans Tezi, 2015.

28. Karaoğlan, AD, Üst düzey yöneticilerin zaman yönetimi, Balıkesir Üniversites Fen Bilimleri Enstitüsü Endüstri Mühendisliği Anabilim Dalı Yüksek Lisans Tezi, 2006.

29. Çitken, P, Zaman yönetimi ve işletme yöneticileri üzerine bir araștırma, Yıldız Teknik Üniversitesi Sosyal Bilimler Enstitüsü Yüksek Lisans Tezi, 1998.

30. Eroğlu, S, Özgür, G, Bir üniversite hastanesinde çalıșan servis ve yoğun bakım hemşirelerinde zaman yönetimi, Gümüşhane Üniversitesi Sağlık Bilimler Dergisi, 2016, 5(1), 12-22.

31. Sayan, İ, Yönetici hemșirelerde zaman yönetimi, Marmara Üniversitesi Sağlık Bilimleri Enstitüsü Yüksek Lisans Tezi, İstanbul, 2005.

32. Boduç, N, Hemşirelerde zaman yönetimi. İstanbul Üniversitesi Sağlık Bilimler Enstitüsü Yüksek Lisans Tezi, 2016.

33. Günüç, S, İnternet bağımlılık ölçeğinin geliştirilmesi ve bazı demografik değiskenler ile internet bağımlılığı arasındaki iliskilerin incelenmesi, Yüzünci Y1l Üniversitesi Sosyal Bilimler Enstitüsü Eğitim Bilimleri Anabilim Dal Yüksek Lisans Tezi, 2009.

34. Alay, S, Kocak, S. Validity and reliability of time management questionnaire Hacettepe Üniversitesi Ĕ̈itim Fakültesi Dergisi, 2002, 22, 9-13.

35. Ückardes, EA. Mersin üniversitesi öğrencileri arasında internet bağımlılığının değerlendirilmesi, Mersin Üniversitesi Tıp Fakültesi Psikiyatri Anabilim Dalı Tipta Uzmanlık Tezi, 2010.

36. Şahin $\mathrm{M}$, İlköğretim okulu öğrencilerindeki internet bağımlılığı, Yeditepe Üniversitesi Sosyal Bilimler Enstitüsü Eğitim Yönetimi ve Denetimi Anabilim Dalı Yüksek Lisans Tezi, 2011

37. Soydan, ZM, Üniversite öğrencilerinin internet bağımlılığ yaşam doyumu arasındaki ilişki, Haliç Üniversitesi Sosyal Bilimler Enstitüs
Psikoloji Anabilim Dalı Uygulamalı Psikoloji Programı Yüksek Lisans Tezi, 2015 .

38. Greenfield, DN, Psychological characters of compulsive internet use: a preliminary analysis. CyberPsychology \& Behavior, 1999, 2(5), 403-412.

39. Başak, T, Uzun, Ş, Arslan, F, Hemşirelik yüksekokulu öğrencilerinin zaman yönetimi becerileri, TAF Preventive Medicine Bulletin, 2008, (5), 429-434.

40. Sarp, N, Yarpuzlu, AA, Mostame, F, Assessment of time management attitudes among health managers, The Health Care Manager, 2005, 24(3), 228-232.

41. Uyanıker, EA, Yönetici hemşirelerin genel öz yeterlilik inancı ile zaman yönetimi arasındaki ilișki, Haliç Üniversitesi Sağlık Bilimleri Enstitüsü Yüksek Lisans Tezi. 2014

42. Balc1, Ş, Gölcü, AA, Öcalan, ME, Üniversite öğrencileri arasında internet kullanım örüntüleri, Selçuk İletişim, 2013, 7(4),5-22.

3. Özcan, NK, Üniversite öğrencilerinde internet kullanımının psikososyal durum ile iliskisi, İstanbul Üniversitesi Sağlık Bilimleri Enstitüsü Doktora Tezi, 2004. 44. Balta, ÇÖ, Horzum, BM, Web tabanlı öğretim ortamındaki öğrencilerin internet bağımlılı̆̆ını etkileyen faktörler. Ankara Üniversitesi Eğitim Fakültesi Dergisi, 2008, 41 (1), 187-205.

45. İssever, NK. Internet bağımlılığının üniversite öğrencilerinde yaygınlığının incelenmesi. Üsküdar Üniversitesi Sosyal Bilimler Enstitüsü Yüksek Lisans Tezi, 2016.

46. Tetik, B, İnternet bağımlılığı ile dikkat süreçleri arasındaki ilişkinin incelenmesi, İstanbul Arel Üniversitesi Sosyal Bilimler Enstitüsü Psikoloji Anabilim Dal Yüksek Lisans Tezi, 2015.

47. Griffiths, MD, Internet abuse in the workplace: issues and concerns for employers and employment counselors, Journal of Employment Counseling, 2003, 40(2), 87- 96 .

48. Yüksel, AK, Hemsirelerde zaman yönetimi ve zaman yönetimini etkileyen faktörler, İstanbul Medipol Üniversitesi Sağlık Bilimleri Enstitüsü Yüksek Lisans Tezi, 2016

49. Sancar, E, Kadınlarda internet bağımlılığı ile ilgili bir araştırma: İstanbul örneği, Iğdır Üniversitesi Sosyal Bilimler Dergisi, 2017, 13, 296-320.

50. Kıdak, LB, Hastane yöneticilerinin zaman yönetimi tutumlarının belirlenmesi: İzmir ili eğitim ve araştırma hastaneleri uygulaması. Selçuk Üniversitesi Sosya Bilimler Enstitüsü Dergisi, 2011, 25, 159-172.

1. Ebrahimi, H, Hosseinzadeh, R, Tefreshi, M, Hosseinzadeh, S, Time managemen behaviors of head nurses and staff nurses employed in Tehran social security hospitals, Iranian Journal of Nursing and Midwifery Research, 2014, 19, 193 199.

52. Chen, SH, An Internet Addiction Measurement for Taiwan College Students, Paper presented in TANET, Taipei, Taiwan (1998).

53. Chou, C, Hsiao, MC, Internet addiction, usage, gratification, and pleasure experience: the Taiwan college students' case, Computers and Education, $2000,35,65-80$

54. Hardie, E, Tee, MY, Excessive internet use: the role of personality, loneliness and social support networks in internet addiction. Australian Journal of Emerging Technologies and Society, 2007, 5(1), 34-47.

55. Tahiroğlu, AY, Çelik, GG, Uzel, M, Özcan, N, Avcı, A, Internet Use Among Turkish Adolescents, CyberPsychology \& Behavior, 2008,11(5),537.

56. Kelleci, M, Güler, N, Sezer, H, Gölbassı, Z, Lise öğrencilerinde internet kullanm süresinin cinsiyet ve psikiyatrik belirtiler ile ilișkisi, Taf Preventive Medicine Bulletin, 2009, 8 (3), 223- 230

57. Tsimtsiou, Z, Haidich, AB, Spachos, D, Kokkali, S, Bamidis, P, Dardavesis, T, Arvanitidou, M, Internet addiction in Greek medical students: an online survey, Academic Psychiatry, 2015, 39(3), 300-304.

58. Turan, RT, Başkent Üniversitesi öğrencilerinde internet bağımlılığı sıklığı ve ilişkili faktörler, Başkent Üniversitesi Tıp Fakültesi Aile Hekimliği Anabilim Dalı Uzmanlık Tezi, 2015.

59. Köse, D, Cınar, N, Akduran, F, Hemșirelik öğrencilerinde internet bağımlıl lŏının kișilik özellikleri ve zaman yönetimi ile ilișkisi, Sakarya University Journal of Science, 2012, 3(16), 227-233.

http://edergi.cbu.edu.tr/ojs/index.php/cbusbed isimli yazarın CBU-SBED başlıklı eseri bu Creative Commons AlıntıGayriticari4.0 Uluslararası Lisansı ile lisanslanmıştır. 